\title{
Shift in functional traits along soil fertility gradient reflects non-random community assembly in a tropical African rainforest
}

\author{
Moses B. Libalah ${ }^{1,2, *}$, Vincent Droissart², Bonaventure Sonké1, Olivier J. Hardy ${ }^{3}$, \\ Thomas Drouet $^{4}$, David S. Pescador ${ }^{5}$, David Kenfack ${ }^{6}$, Duncan W. Thomas ${ }^{7}$, \\ George B. Chuyong ${ }^{8} \&$ Pierre Couteron $^{1,2}$
}

\author{
${ }^{1}$ Plant Systematic and Ecology Laboratory (LaBosystE), Department of Biology, Higher Teachers' Training College, University of Yaoundé \\ I, P.O. Box 047, Yaoundé, Cameroon \\ ${ }^{2}$ AMAP, IRD, CNRS, INRA, Université Montpellier, Bd de la Lironde TA40/PS2 - 34398, Montpellier, France \\ ${ }^{3}$ Université Libre de Bruxelles, Faculté des Sciences, Evolutionary Biology and Ecology Unit, CP 160/12, Av. F.D. Roosevelt 50, B-1050 \\ Brussels, Belgium \\ ${ }^{4}$ Université Libre de Bruxelles, Plant Ecology and Biogeochemistry Unit, CP 244, Boulevard du Triomphe, B-1050 Brussels, Belgium \\ ${ }^{5}$ Biología y Geología, Física y Química Inorgánica, Universidad Rey Juan Carlos, E-28933 Móstoles, Madrid, Spain \\ ${ }^{6}$ CTFS - ForestGEO, Smithsonian Tropical Research Institute, NMNH, P.O. Box 37012, Washington, DC 20013-7012, USA \\ ${ }^{7}$ School of Biological Sciences, Washington State University, P.O. Box 644236, Pullman, WA 99164-4236, USA \\ ${ }^{8}$ Department of Botany and Plant Physiology, University of Buea, P.O. Box 063, Buea, Cameroon \\ *Author for correspondence: libalah_moses@yahoo.com
}

\begin{abstract}
Background and aims - There is increasing recognition that plant traits mediate environmental influence on species distribution, justifying non-random community assembly. We studied the influence of local scale edaphic factors on the distribution of functional traits in a tropical rainforest of Cameroon with the aim to find correlations between the main edaphic gradient and community functional trait metrics (weighted mean trait, functional divergence and intraspecific variation).

Methods - Within the Korup Forest Dynamics Plot (50 ha), we randomly selected 44 quadrats of 0.04 ha each, collected soils and analysed 11 topography and soil variables. Leaves were harvested from all 98 tree species found in the quadrats to calculate community trait metrics [quadrat-level weighted mean $\left(q_{k}\right)$ and functional divergence $\left(F D i v_{k}\right)$ ] for leaf area (LA), specific leaf area (SLA), leaf phosphorus (LPC), leaf nitrogen concentration (LNC) and nitrogen to phosphorus ratio (N:P ratio). We examined relationships between the main edaphic gradient with $q_{k}$, with $F D i v_{k}$ and with intraspecific variation and interpreted correlations as the effects of abiotic filtering and competitive interaction.

Key results - Soil fertility was the main edaphic gradient and was significantly correlated with $q_{k}$ for LPC, LNC and LA and with FDiv $v_{k}$ for LPC, N:P ratio, LA and SLA, confirming the influence of abiotic filtering and competitive interaction by the soil fertility gradient, respectively. For a given trait, quadrats were either over-dispersed or under-dispersed, accounting for $7-33 \%$ of non-random trait distribution along the soil fertility gradient. Trends in intraspecific traits variation were consistently lower than quadrat-level mean traits along the soil fertility gradient.

Conclusions - This study demonstrates the influence of soil fertility gradient on local scale community trait distribution and its contribution to non-random community assembly.
\end{abstract}

Key words - Abiotic filtering, Cameroon, intraspecific trends, Korup National Park, leaf traits.

\section{INTRODUCTION}

Understanding the distribution of plant species and structural types along gradients at different spatial scales is a major goal in community ecology (HilleRisLambers et al. 2012). Functional traits have shown to mediate species response to environmental gradients, shift plant strategies within and among communities, and inform on community assembly processes (Keddy 1992, Díaz \& Cabido 1997, Lavorel \& Garnier 2002, Westoby et al. 2002, McGill et al. 2006). Functional traits can also inform on intraspecific variation, species coexistence and prevailing environmental conditions 
(Cornwell \& Ackerly 2009). This knowledge about traits has therefore led to the identification of different trait-response strategies for leaf (Wright et al. 2004), wood (Chave et al. 2009) and whole plant (Reich 2014, Díaz et al. 2015).

Studies on the relationships between functional traits and environment conditions across biomes have summarized a suite of traits that represent some general trade-offs or "economic spectra" (Shipley et al. 2006, Reich 2014). For example, in the leaf economic spectrum "slow-growing" plants with long-lived leaves, low values of specific leaf area (SLA), leaf phosphorus concentrations (LPC), leaf nitrogen content (LNC) and photosynthetic capacity are often associated with nutrient-poor soils (Wright et al. 2001, Ordoñez et al. 2009). In this case, traits may enhance resource-use efficiency by increasing photosynthetic carbon gain per unit of nutrient uptake. In contrast, "fast-growing" plants with the opposite sets of traits (short-lived leaves, high SLA, LPC, LNC and a high photosynthetic capacity) are rather associated with nutrient-rich soils (Wright et al. 2001, 2004). Thus a certain suite of traits may maximize growth rate and enhance competitive advantage under certain soil nutrient conditions and be detrimental in others (Weiher \& Keddy 1995). Other traits such as the leaf area (LA), not considered in the leaf economic spectrum (sensu Wright et al. 2004) are equally important in trait-environment studies (Engelbrecht \& Kursar 2003, Paoli 2006, Hulshof \& Swenson 2010, Kichenin et al. 2013). Therefore, traits that capture species resource-use and competitive strategy may be expected to be associated with a shift in soil nutrient conditions.

Environmental filtering and competitive interactions often represent two major processes which can have both synergistic and opposing effects on community assembly (Keddy 1992, Diaz et al. 1998, Weiher et al. 1998). First, environmental filtering prevents or limits the inclusion of species without physiological tolerance to the abiotic conditions, resulting to trait convergence of co-occurring species in a community (Diaz et al. 1998, Weiher et al. 1998). This process can influence both interspecific trait variation by changing the composition and/or abundances of species in a community (Ackerly \& Cornwell 2007), and intraspecific trait variation because of trait plasticity and genetic variability (Jung et al. 2010, Violle et al. 2012, Auger \& Shipley 2013). Second, interspecific competitive interaction is expected to limit the ecological similarity between species, leading to trait divergence of co-occurring species in a community (Macarthur \& Levins 1967, Schwilk \& Ackerly 2005). Other processes, such as "stabilizing niche differences" or "relative fitness differences" also contribute to community assembly via trait divergence or convergence. For example, stabilizing niche differences in the form of resource partitioning, hostspecific natural enemies, or storage effects cause species to strongly limit themselves than others (HilleRisLambers et al. 2012). Contrarily, relative fitness differences improve coexistence between species because of equal competitive ability for the uptake of limited resources and/or tolerate herbivores (Chesson 2000, HilleRisLambers et al. 2012).

Trait-based metrics have been devised and tested (for a review, see Villéger et al. 2008, Mouchet et al. 2010) to infer the contribution of assembly processes in shaping ecological communities. Community-level weighted means (CWA) and functional divergence (dissimilarities between co-occurring species), have been used to describe and interpret the distribution of functional traits within- and among- plant communities (Lavorel \& Garnier 2002, Lavorel et al. 2008, de Bello et al. 2013). For instance Spasojevic \& Suding (2012) interpreted a decrease of CWA trait values of leaf area and plant height along a nutrient availability gradient as the effects of abiotic filtering, while an increase in functional diversity of tree height and leaf area with corresponding increase in soil depth, moisture and nitrogen availability was interpreted as competition for light or facilitation.

Recent urges to consider intraspecific variation in traitbased studies argued that CWA largely ignore intraspecific variation (Albert et al. 2010, 2011, Bolnick et al. 2011, Violle et al. 2012, Auger \& Shipley 2013). These studies pointed that intraspecific variation allows the possibility for individuals within a local community to exhibit varying ecological strategies thereby increasing species niche breadth (Violle et al. 2012). Recently, studies have focused on the relative contribution of intraspecific and interspecific trait variation (de Bello et al. 2011, Lepš et al. 2011, Siefert 2012, Siefert et al. 2014, Pescador et al. 2015). The overall result supports that intraspecific variation, though generally smaller than interspecific variation, represents a non-negligible contribution to community trait composition and assembly (Jung et al. 2010, 2014, Siefert 2012, Kichenin et al. 2013). It will probably be interesting to examine the relative trend of intraspecific variation with respect to the community trend along environmental gradients, a concern which is barely present in literature (but see Pescador et al. 2015, Cornwell \& Ackerly 2009).

Soils of tropical rainforests are generally nutrient-poor. This encourages the debate about edaphic influence on functional traits at local scales (Xia et al. 2015). This is the case in Southwestern Cameroon and in the 50-ha Korup Forest Dynamics Plot (hereafter, 50-ha KFDP) where the soils are impoverished because heavy rainfall causes weathering and leaching, leading to the removal of nutrients and clay particles (Newbery et al. 1988, 1998, Chuyong et al. 2004). Sand and silt contents are also reported to reach up to $70 \%$ in some areas of the forest (Newbery et al. 1998), which can be explained by the derivation of those soils from old granite and quartzite rocks (Precambrian) (Gartlan et al. 1986) or maybe Arenosols. Floristic distribution in this forest is driven by topography, soil moisture and soil composition (Gartlan et al. 1986, Baldeck et al. 2013), habitat conditions (Chuyong et al. 2011) and possibly ectomycorrhizae (Newbery et al. 1988), with $>98 \%$ of trees forming mycorrhizal association (Bechem et al. 2014).

Here we examine, at a local scale, how and to what extent leaf traits may be associated with a gradient in soil properties in the Korup Forest. We measured four functional traits on trees present in $20 \mathrm{~m} \times 20 \mathrm{~m}$ quadrats within the 50-ha KFDP and analysed eleven variables related to topography and soil composition. Specifically, we: (1) identified the main edaphic gradients; (2) examined how shifts in quadrat-level weighted mean trait (interpreted as linked to abiotic filtering) and in functional divergence (interpreted as relating to competitive interaction) were associated with gradients of soil composition; (3) tested for non-random trait distribution by comparing trait values of observed versus simulated communities 
built from null models that assume random assembly; and (4) determined the trends of intraspecific trait variation along the main soil gradients. We hypothesized that abiotic filtering would be strong for quadrats with low soil fertility (lower mean trait values) and weak for quadrats with high soil fertility (higher mean trait value) while competitive interaction would be less important for quadrats with high soil fertility (higher functional divergence) and more important for quadrats with low soil fertility (lower functional divergence).

\section{MATERIALS AND METHODS}

\section{Study location}

This study was conducted in the 50 -ha KFDP $\left(5^{\circ} 03.86^{\prime} \mathrm{N}\right.$ $8^{\circ} 51.17^{\prime}$ E, fig. 1) which is located within Korup National Park (Southwestern Cameroon). The climate in this area is bi-seasonal with a short - three months - dry season and a long - nine months - rainy season. Mean annual rainfall can reach $5300 \mathrm{~mm}$ and temperature $27^{\circ} \mathrm{C}$ (Chuyong et al. 2004). The rainforests of the Korup National Park are described as Biafran forest type; rich in species and dominated by gregarious stands of Fabaceae-Caesalpinioideae (Letouzey 1985) and overlapped with a possible Pleistocene refuge of central African coastal forests (Maley 1998). The floristic composition of the 50-ha KFDP is diverse, host to many rare and abundant species of the region (Kenfack et al. 2007), and new species are discovered regularly (Libalah et al. 2014, Kenfack et al. 2015, Ewango et al. 2016). All woody plant species in the plot with a diameter at breast height (dbh) equal or greater than one centimetre, is been monitored (i.e. tagged, mapped and identified) since 1996 (Chuyong et al. 2004, Kenfack et al. 2007).

The soils of Korup forest are mostly sandy and nutrientpoor with a soil available phosphorus as low as 2 ppm (Gartlan et al. 1986) due to heavy rainfall which leach and deplete soil nutrients. In the 50-ha KFDP, the soils are ferralitic (or sometimes Arenosol) and may have developed from in situ weathering of granite bedrocks. This forest block is also characterized by heterogeneous soil and topography; soils of the northern higher slope of the plot are dryer and thinner (presence of large embedded rocks) while at the southern lower plain, soils are wetter and deeper (almost absence of embedded rocks). Between these two extremes are boulders and gullies that channel streams and surface run-offs to the lower temporally flooded plane of the 50-ha KFDP.

\section{Sampling strategies}

Plot establishment and topography of the 50-ha KFDP The 50-ha KFDP measures $1000 \mathrm{~m}$ long by $500 \mathrm{~m}$ wide and has a short altitudinal range between 150 and $240 \mathrm{~m}$ a.s.l. (fig. 1). It has been divided into 1250 quadrats of $20 \mathrm{~m} \times$ $20 \mathrm{~m}(0.04 \mathrm{ha})$. The elevation, slope and convexity of each quadrat were measured (details on plot establishment and tree censuses are found in Thomas et al. 2003, Chuyong et al. 2004, 2011). The elevation was measured in the field to the nearest $0.1 \mathrm{~m}$ at each corner of the quadrat and the value added to the absolute elevation got from the published survey map of the area. The slope was measured by forming three angles and measuring the deviation from the horizon of each of the triangular planes. Convexity was calculated as the difference between the mean elevation of the focal quadrat and the mean elevation of the eight surrounding quadrats. For quadrats at the edge, convexity was calculated as the difference between the elevation of the centre of the focal quadrat and the mean elevation of the four corners. Using these three topographic attributes for each quadrat, Chuyong et al. (2011) assigned each quadrat to one of five habitat types. For this study, we carried out a stratified sampling by randomly sampling 8-10 quadrats within each habitat type and collected soil samples and leaf traits (fig. 1).

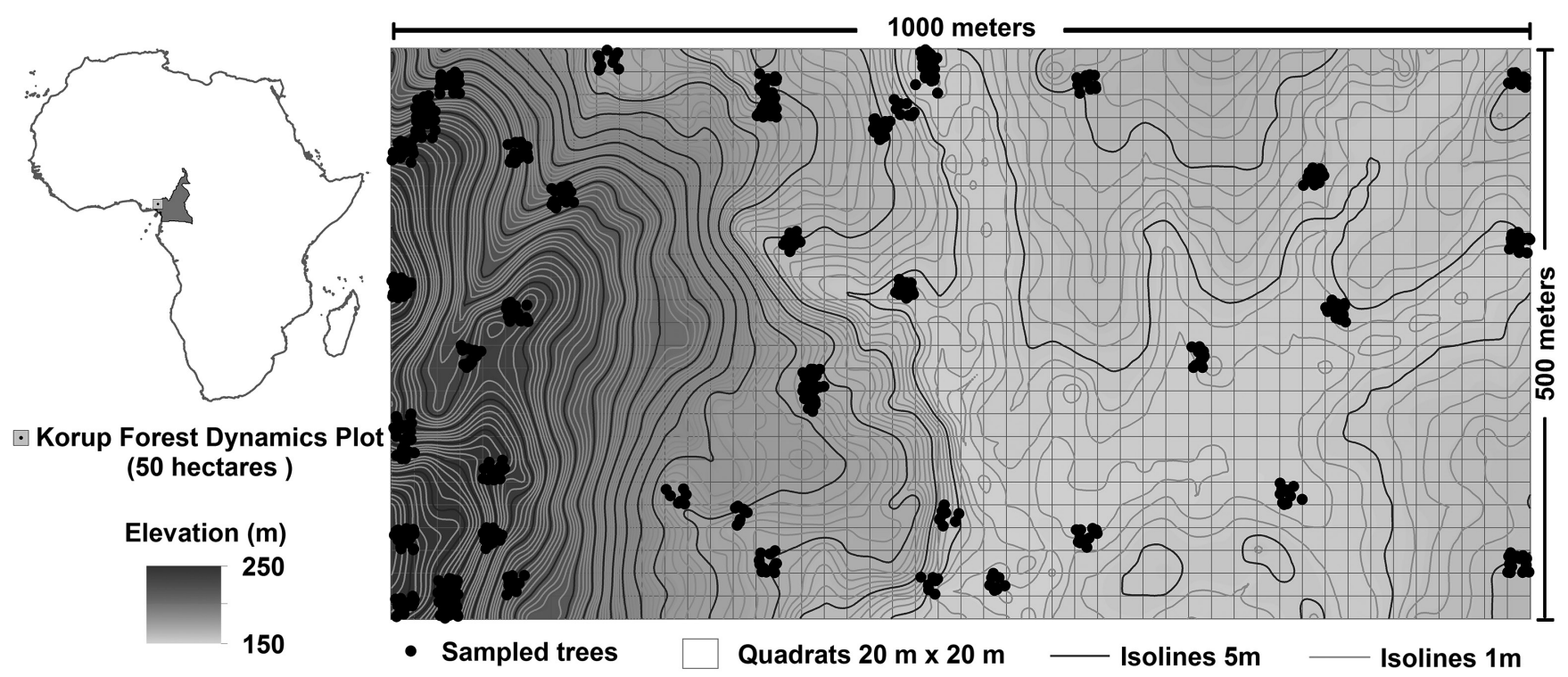

Figure 1 - Location of the 50-ha Korup Forest Dynamics Plot in southwestern Cameroon and distribution of the sampled trees (black dots) within the plot. Traits and soils were sampled within 44 quadrats of $20 \mathrm{~m} \times 20 \mathrm{~m}$ (0.04 ha). Maps were prepared with ArcMap 10.4.1 (ESRI 2016). The elevation model and isolines were computed to the nearest $0.1 \mathrm{~m}$ plus the absolute elevation obtained from local survey maps. 
Table 1 - Summary statistics of the topography and soil-related variables used in this study for the analysis of edaphic gradient. For each variable, the minimum, maximum, mean and standard deviation and codes are provided.

\begin{tabular}{|c|c|c|c|c|c|c|c|c|c|c|c|}
\hline $\begin{array}{l}\text { Code } \\
\text { (unit) }\end{array}$ & $\begin{array}{c}\text { Total } \\
\text { nitrogen } \\
\text { NIT } \\
\left(\mathrm{g} \mathrm{kg}^{-1}\right) \\
\end{array}$ & $\begin{array}{c}\text { Total } \\
\text { phosphorus } \\
\text { TPH } \\
\left(\mathrm{g} \mathrm{kg}^{-1}\right) \\
\end{array}$ & $\begin{array}{c}\text { Sand } \\
\text { content } \\
\text { SAND } \\
(\%) \\
\end{array}$ & $\begin{array}{c}\text { Silt } \\
\text { content } \\
\text { SILT } \\
(\%) \\
\end{array}$ & $\begin{array}{c}\text { Cation exchange } \\
\text { capacity } \\
\text { CEC } \\
\left(\mathrm{cmol} \mathrm{kg}^{-1}\right) \\
\end{array}$ & $\begin{array}{c}\text { Organic } \\
\text { matter } \\
\text { ORM } \\
(\%) \\
\end{array}$ & $\begin{array}{c}\text { Clay } \\
\text { content } \\
\text { CLAY } \\
(\%) \\
\end{array}$ & $\begin{array}{c}\text { Moisture } \\
\text { content } \\
\text { MOC } \\
(\%) \\
\end{array}$ & pHW & $\begin{array}{l}\text { Elevation } \\
\quad(\mathrm{m})\end{array}$ & $\begin{array}{c}\text { Slope } \\
\left(^{\circ}\right)\end{array}$ \\
\hline Min. & 0.17 & 22.51 & 27.75 & 2.94 & 1.88 & 10.95 & 10.99 & 0.81 & 4.30 & 278.82 & 2.55 \\
\hline Max. & 2.30 & 2375.59 & 51.08 & 9.07 & 9.39 & 42.96 & 32.07 & 11.86 & 5.97 & 373.74 & 30.96 \\
\hline Mean & 1.31 & 432.18 & 38.17 & 5.12 & 5.45 & 27.67 & 20.68 & 4.08 & 5.10 & 313.10 & 11.74 \\
\hline SD & 0.39 & 506.26 & 5.48 & 1.25 & 1.98 & 7.73 & 4.29 & 2.52 & 0.31 & 33.49 & 7.75 \\
\hline
\end{tabular}

Soil variables - We collected soil samples to $30 \mathrm{~cm}$ depth from the selected quadrats and analysed eight soil mineral resources. The samples were first air-dried and ground to pass through a $2 \mathrm{~mm}$ sieve using a motorized - Retch RM200® - grinder and further fine-ground to pass through a $0.5 \mathrm{~mm}$ sieve for Nitrogen and Carbon analyses. Soil $\mathrm{pH}$ in water (pHW) was determined in a 1:2.5 (w/v) soil:water suspension. Total nitrogen (NIT, $\mathrm{g} \mathrm{kg}^{-1}$ ) and Total phosphorus (TPH, $\mathrm{g} \mathrm{kg}^{-1}$ ) were determined from a wet acid digest and analysed by colorimetry (Anderson \& Ingram 1993, Buondonno et al. 1995) and TPH was further determined using the molybdate blue procedure described by Murphy \& Riley (1962). Cation exchange capacity (CEC, cmol $\mathrm{kg}^{-1}$ ) was determined using ammonium acetate at $\mathrm{pH}$ 7. Moisture content (MOC, \%) was determined by gravimetry after sample drying at $105{ }^{\circ} \mathrm{C}$. Organic carbon was determined by chromic acid digestion and spectrophotometric analysis using a Genesys 10S UV/ Vis spectrophotometer. Soil organic matter (ORM, \%) was then obtained by multiplying organic carbon value by 1.72 (Heanes 1984). Particle sizes (Sand, \%; Silt, \%; and Clay, $\%$ ) were determined by the Bouyoucos hydrometry (Bouyoucos 1951, Day 1953). Summary statistics of the soil and topography variables are presented in table 1 . The analyses of soil mineral resources were conducted in the plant and soil laboratory of the Institut de la Recherche Agricole pour le Développement (IRAD), Cameroon.

Individual trees and leaf traits data - From the 44 quadrats (0.04 ha each) which were randomly selected, we used a collecting pole and ladder each $5 \mathrm{~m}$ long to sample all trees with $\mathrm{dbh} \geq 10 \mathrm{~cm}$. Individuals that presented physiological deformation or obvious symptoms of pathogen or herbivore attack were not sampled. Integrating such individuals in our dataset may have reflected the modified physiological status of the plants rather than their ecological functioning (Cornelissen et al. 2003). Individuals with tall inaccessible canopies were not also sampled for practical reasons. A total of 489 individuals were sampled (fig. 1), representing an average of eleven trees per quadrat.

We harvested three fully opened sun leaves (leaf blade plus petiole) from each tree during the months of June-July 2015 . The fresh leaves were spread in-between a $25 \mathrm{~cm} \times 50$ $\mathrm{cm}$ white surface (below) and a transparent sheet (above) to take a high-resolution photograph without shadow. The photograph was analysed with TOASTER; an ImageJ software plugin (Borianne \& Brunel 2012), to obtain automatically leaf area values for the three leaves. These leaves were later oven-dried with a Genlab OV/50® oven at $70{ }^{\circ} \mathrm{C}$ to constant weight and weighed with an OHAUS scout ${ }^{\circledR}$ pro sp202 balance (mass precision of $0.01 \mathrm{~g}$ ), to obtain their dry masses. Leaf area $\left(\mathrm{LA}, \mathrm{cm}^{2}\right)$ per tree was determined as the average area of the three leaves; specific leaf area (SLA, $\mathrm{mm}^{2} \mathrm{mg}^{-1}$ ) was calculated as the ratio between LA and the average mass of the three leaves. These analyses were conducted at the Plant Systematic and Ecology Laboratory, University of Yaoundé I, Cameroon.

To measure the concentrations of $\mathrm{P}$ and $\mathrm{N}$ of the leaves, equal fractions from each of the three leaves were cut, mashed and homogenized using a Retch RM200 ${ }^{\circ}$ grinder and dried at $105{ }^{\circ} \mathrm{C}$ for $48 \mathrm{~h}$ to exclude moisture. Then, $0.2 \mathrm{~g}$ of the powder was weighed using a Sartorius R200D ${ }^{\circledR}$ balance (mass precision of $1 \times 10^{-6} \mathrm{~g}$ ) and further calcinated at $450{ }^{\circ} \mathrm{C}$ in a Lenton ARF ${ }^{\circledR}$ furnace. The phosphorus concentration (LPC, $\mu \mathrm{g} \mathrm{g}^{-1}$ ) of the vegetated sample was determined by acid dissolution of the ashes followed by a colorimetric determination with the molybdenum blue method (John 1970). From another $0.2 \mathrm{~g}$ powder, nitrogen content (LNC, $\left.\mu \mathrm{g} \mathrm{g}^{-1}\right)$ of the sample was determined by flash combustion at $950{ }^{\circ} \mathrm{C}$ in a C-N elemental analyser (Dumas method). These were realized at the Plant Ecology and Biogeochemistry Unit, Université Libre de Bruxelles, Belgium.

Trait measurements for LPC and LNC on all individuals were too costly to be envisaged. To reduce the cost, we selected four species and measured LPC and LNC on the individuals. We selected Cola rostrata K.Schum., Hymenostegia afzelii (Oliv.) Harms, Oubanguia alata Baker f., and Strombosiopsis tetrandra Engl. because they are widely distributed in Southwestern Cameroon and also among the most abundant trees in the 50-ha KFDP (Kenfack et al. 2007 and electronic appendix 1). Further, we measured LPC on a bulk sample for each species. This was done by mixing equal leaf fractions of all individuals of the species irrespective of the quadrat it was sampled. Each bulk sample yielded a value used as the species mean for LPC. For LNC, measurement was limited to the four species mentioned above.

\section{Trait-based community analysis}

Functional trait metrics - We used the trait-gradient approach of Ackerly \& Cornwell (2007) to compute the functional trait metrics. We computed a species mean trait $\left(t_{i}\right)$ and a community-weighted mean trait (that is, a quadrat-level weighted mean trait in our case; $q_{k}$ ): 
$t_{i}=\frac{\sum_{k=1}^{p} a_{i k} \times t_{i k}}{\sum_{k=1}^{p} a_{i k}}$

$q_{k}=\frac{\sum_{i=1}^{S} a_{i k} \times t_{i k}}{\sum_{i=1}^{S} a_{i k}}$

Where $t_{i}$ (equation 1) represents the $i^{\text {th }}$ species mean trait and $q_{k}$ (equation 2) abundance-weighted quadrat-level mean values, $t_{i k}$ being the trait value of species $i$ in quadrat $k$ and $a_{i k}$ is the abundance of species $i$ in quadrat $k$. The total number of species and quadrats in the study is $\mathrm{S}$ and $P$, respectively. Note that for LPC, only one value from the bulk sample was used as species mean trait and for LNC only four species were involved. Equation 1 (species metric) computes the species mean and sums species' traits irrespective of the quadrats while equation 2 (community metric) computes the quadrat mean trait and sums quadrat trait values irrespective of species.

We equally calculated functional divergence $\left(F D i v_{k}\right)$ using the Rao's diversity coefficient (Botta-Dukát 2005). The FDiv ${ }_{k}$ represents the sum of pairwise trait dissimilarities between species within a quadrat, weighted by the species relative abundance (Botta-Dukát 2005, Mouchet et al. 2010). We computed the uni-trait and unstandardized FDiv $v_{k}$ using the formula:

$$
F D i v_{k}=\sum_{i=1}^{S} \sum_{j=i+1}^{S-1} d_{i j} a_{i} a_{j}
$$

where $d_{i j}$ is the trait dissimilarity between each pair of species $i$ and $j\left(d_{i k}=d_{k i}\right.$ and $\left.d_{i i}=0\right), a_{i}$ and $a_{j}$ are the relative abundance vectors of species $i$ and $j$ and $S$ is the total number

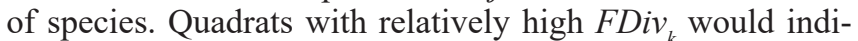
cate a high degree of niche differentiation, and thus low resource competition (Mason et al. 2005).

Determining the main edaphic gradients - To identify the main gradients from the topography and soil properties, we conducted a standardized principal component analysis (PCA) on the eight soil variables measured in each of the 44 quadrats. We included elevation and slope as supplementary quantitative variables in the PCA to facilitate interpretation of results through correlation between the main PCA axes. We applied Kaiser-Guttman's criterion to select the main interpretable PCA axes. Unlike most selection methods based on visual inspection of PCA axes, this method computes the mean of all eigenvalues and conserves only the axes whose eigenvalues are greater than the mean, i.e. eigenvalues $\geq 1$ for standardized PCA (Borcard et al. 2011). The choice of a PCA follows preliminary analysis based on multiple linear regressions between traits values (response) and individual soil variables. The correlation and variation coefficients were not significant in all but one analysis (results not shown).

Association of functional traits with edaphic gradients To examine how a shift in the edaphic gradients may be associated with functional traits, we fitted linear models for each trait separately by using the quadrat-level weighted mean trait $\left(q_{k}\right)$ and functional divergence $\left(F D i v_{k}\right)$ vs. the scores of the main PCA axes. We interpreted significant correlations between the main PCA axes vs. $q_{k}$, as the effect of abiotic filtering, and vs. FDiv $v_{k}$ as the effect of competitive interaction.

Non-random community trait distribution - To determine whether the trait-edaphic gradient associations were nonrandom, we used a null model which assumes that traits are randomly distributed within quadrats. We generated the null communities by randomizing species traits values within each quadrat by species matrices. Species abundances within each quadrat were kept constant but traits were shuffled across species. We estimated a null $q_{k}$ and FDiv $v_{k}$ for each quadrat and calculated $95 \%$ confidence intervals (CI) after 999 repetitions of the null model. We computed the differences between the observed communities and the null (i.e. observed $q_{k}-$ null $q_{k}$ and observed FDiv $v_{k}-$ null FDiv $v_{k}$. Positive or negative differences were interpreted as the effects of trait convergence or divergence, respectively.

Trends of intraspecific trait variation across gradients - To assess intraspecific trait variation patterns relative to quadrat-level mean trait $\left(q_{k}\right)$ we performed linear regressions on individual trait values of the $i$ th species in a quadrat $\left(t_{i k}\right)$ vs. the $q_{k}$ and interpreted the slope of the regression to be the intraspecific trait variation. We recognize that $t_{i k}$ and $q_{k}$ are mathematically not independent, that is, $t_{i k}$ is included in the calculation of $q_{k}$. This may lead to false correlation even without an ecological relationship. To correct for this, we used the Jackknife analysis to recalculate the $q_{k}$ but without accounting for focal species in the quadrat (Cornwell \& Ackerly 2009). We further performed linear regressions between $t_{i k}$ and the scores of the main PCA axes to assess intraspecific trait response to the gradient. We used the abundanceweighted ordinary least squares regression to examine the trends of intraspecific trait variation across the gradients.

Statistical analyses were performed in $\mathrm{R}$ version 3.2.2 (R Development Core Team 2015), using the following packages: FactoMinR (Lê et al. 2008) for PCA; vegan (Oksanen et al. 2012) to generate null communities; $F D$ (Laliberté et al. 2014) to compute $q_{k}$ and $F D i v_{k}$. We checked that traits were normally distributed after applying square root transformation on LA, LPC and N:P ratio and $\log _{10}$ transformation on SLA and LNC.

\section{RESULTS}

\section{Floristic overview}

A total of 489 individual trees $(\mathrm{dbh} \geq 10 \mathrm{~cm})$ from 98 species (75 genera and 37 families) were sampled from 44 quadrats of 0.04 ha each (see electronic appendix 1). Five species had the highest number of individuals in the dataset: Oubanguia alata Baker f. (75); Drypetes staudtii (Pax) Hutch. (42); Hymenostegia afzelii (Oliv.) Harms (24); Cola rostrata K.Schum. (23) and Strombosiopsis tetrandra Engl. (15), which are also among the most dominant species in the 50- ha KFDP. We recorded 17 species common in at least seven quadrats (16\%), 46 species were sampled in one quadrat only and 14 quadrats hosted more than ten species. 
Table 2 - Identification of the main gradients in topography and soil-related variables in the 50-ha Korup Forest Dynamics Plot. Ten soil-related variables were measured from forty-four 0.04 ha quadrats. Dim. 1, Dim. 2 and Dim. 3 represent the main axes of a principal component analysis. Pearson correlation coefficient and level of significance (n.s. $=$ not significant, ${ }^{*} \mathrm{p}<0.05, * * \mathrm{p}<0.01, * * * \mathrm{p}<0.001$ ) between the main axes and measured variables are provided.

\begin{tabular}{|c|c|c|c|}
\hline & Dim. 1 & Dim. 2 & Dim. 3 \\
\hline Eigenvalues & 3.07 & 1.82 & 1.13 \\
\hline$\%$ of variance & 34.17 & 20.28 & 12.62 \\
\hline Cumulative $\%$ of variance & 34.17 & 54.45 & 67.07 \\
\hline Sample size & 44 & 44 & 44 \\
\hline Interpretation & $\begin{array}{l}\text { Soil fertility } \\
\text { gradient }\end{array}$ & $\begin{array}{l}\text { Soil texture } \\
\text { gradient }\end{array}$ & $\begin{array}{c}\text { Soil phosphorus } \\
\text { gradient }\end{array}$ \\
\hline Nitrogen $\left(\mathrm{g} \mathrm{kg}^{-1}\right)$ & $0.69 * * *$ & $-0.45 * *$ & $-0.44 * *$ \\
\hline Phosphorus ( $\left.\mathrm{g} \mathrm{kg}^{-1}\right)$ & $0.37 * * *$ & $0.33 * *$ & $0.79 * * *$ \\
\hline Sand content $(\%)$ & $-0.37 *$ & $-0.71 * * *$ & $0.31 *$ \\
\hline Silt content $(\%)$ & $-0.4 * *$ & $0.77 * * *$ & - \\
\hline Cation exchange capacity $\left(\mathrm{cmol} \mathrm{kg}^{-1}\right)$ & $0.87 * * *$ & - & - \\
\hline Organic matter $(\%)$ & $0.83 * * *$ & - & - \\
\hline Clay content $(\%)$ & $0.77 * * *$ & - & - \\
\hline Moisture content $(\%)$ & - & $0.49 * * *$ & - \\
\hline Elevation (m) & $0.71 * * *$ & $0.1 \mathrm{n} . \mathrm{s}$. & $0.21 \mathrm{n} . \mathrm{s}$. \\
\hline Slope $\left(^{\circ}\right)$ & $0.61 * * *$ & 0.08 n.s. & 0.25 n.s. \\
\hline
\end{tabular}

\section{Main edaphic gradients}

Using Kaiser-Guttman's criterion, three PCA axes were retained to summarize the main gradients from the soil variables and accounted for $67 \%$ of the total variance (table 2 ). The first PCA axis (Dim. 1) explaining approximately $34 \%$ of total variance, was related to soil mineral resources and topography (supplementary variable). Thus this first axis described a soil gradient of increasing CEC, ORM, Clay, TPH and NIT, and strongly and positively correlated to elevation $(\mathrm{r}=0.71, \mathrm{p}$-value $<0.001)$ and to slope $(\mathrm{r}=0.61$, $\mathrm{p}$-value $<0.001$ ) (table $2 \&$ electronic appendix 2). We interpreted Dim. 1 as a gradient of soil fertility because of the higher proportion of CEC, ORM and Clay which are all fertilityrelated soil properties. The second axis (Dim. 2), accounting for $20 \%$ of total variance and was interpreted as a soil texture gradient because of the strong correlation with sand $(\mathrm{r}=-0.71$, p-value $<0.0001)$ and silt contents $(\mathrm{r}=0.77$, $\mathrm{p}$ value $<0.0001)$. This axis was also negatively correlated to NIT but positively correlated to soil moisture content. The third axis (Dim. 3), explaining $13 \%$ of the total variance, was interpreted as a gradient of phosphorus content. TPH was positive while NIT was negatively correlated to this axis. The latter two gradients were not significantly correlated with elevation and slope (table 2). We retained the soil fertility gradient (Dim. 1) to explore further trait-gradient analysis since Dim. 2 and Dim. 3 were not significantly correlated to quadrat-level mean trait values and functional divergence (see results on electronic appendix 3). We, however, acknowledge that some important constituents of fertil- ity, namely $\mathrm{P}$ and to some extent $\mathrm{N}$ were partly independent of Dim. 1. Elevation and slope were strongly correlated to Dim. 1 (table $2 \&$ electronic appendix 2) and therefore were not considered in further trait-gradient analyses.

\section{Association of functional traits with soil fertility gradient}

The association between functional traits and the soil fertility gradient was significant for three quadrat-level mean trait and four functional divergence traits (fig. 2). Of the two functional trait metrics, trait association with the soil fertility gradient was highly variable among the traits. For example, quadrat-level mean trait for LPC, LNC and LA was positively correlated (from $r=0.32$ to $r=0.40$ ) with the soil fertility gradient while no significant association was observed for SLA versus soil fertility (fig. 2A-E). Functional divergence (i.e. within quadrat dissimilarities between species' trait) showed two patterns: species were either more dissimilar for LA and SLA or less dissimilar for LPC and N:P ratio, as the gradient in soil fertility increases (fig. 2F-J). However, no correlation was observed for functional divergence of LNC along the soil fertility gradient (fig. 2G).

\section{Non-random community trait distribution}

Quadrat-level weighted mean trait distribution and functional divergence along the soil fertility gradient were significantly different from the null assumption of random trait distribution. These differences varied among the traits and were either positive (trait convergence) or negative (trait 
divergence) (fig. 3). Quadrat-level weighted mean for LPC, LNC and LA but not N:P ratio increased toward the more fertile end of the soil gradient, i.e. trait variation based on species' mean trait values was higher than expected in these traits for quadrats on more fertile soils and lower than expected for quadrats on less fertile soils (fig. 3A, B \& D). Functional divergence of LPC, LA and SLA showed two patterns: divergence of LPC decreased as the gradient in soil fertility increased (fig. 3E) while divergence in LA and SLA increased as the gradient in soil fertility. More divergence, therefore, occurred in quadrats on less fertile soils than those on more fertile soils for LPC contrary to LA and SLA. Nonrandom trait distribution also changed depending on the trait. For instance, non-random trait distribution accounted for
$13 \%$ and $33 \%$ of species' dissimilarity between quadrats and $15 \%$ and $30 \%$ of species' mean trait variation between quadrats for LA and LPC, respectively (fig. 3).

\section{Trends in intraspecific trait variation}

Results of the Jackknife analysis showed that intraspecific trait variations differed from the quadrat-level mean trait variation in strength and direction (fig. 4 \& electronic appendix 4). Interpreting the slopes of the regression lines connecting individuals of the same species, the intraspecific trait variation was obtained for 43 species present in three or more quadrats (see electronic appendix 4). Overall, the slopes of intraspecific trait variation ranged from -8.33 to 3.94 but these variations changed between the traits and were either in
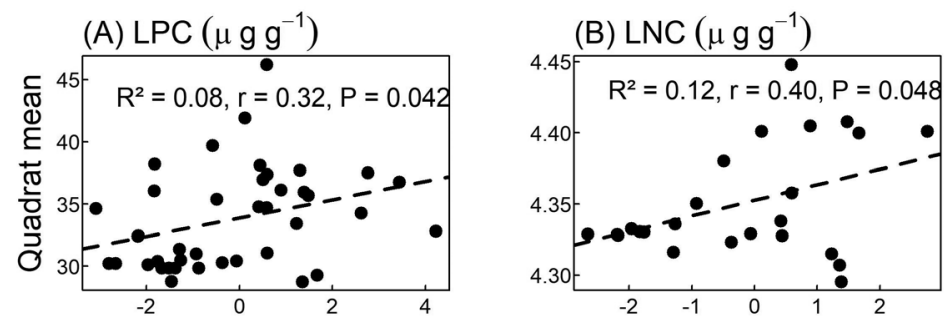

(C) $\mathrm{N}: \mathrm{P}$ ratio

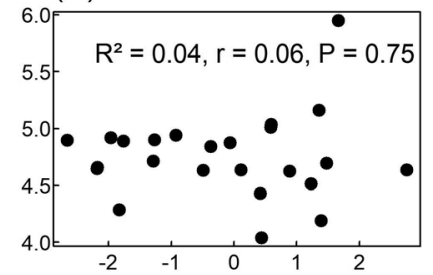

(D) LA $\left(\mathrm{cm}^{2}\right)$
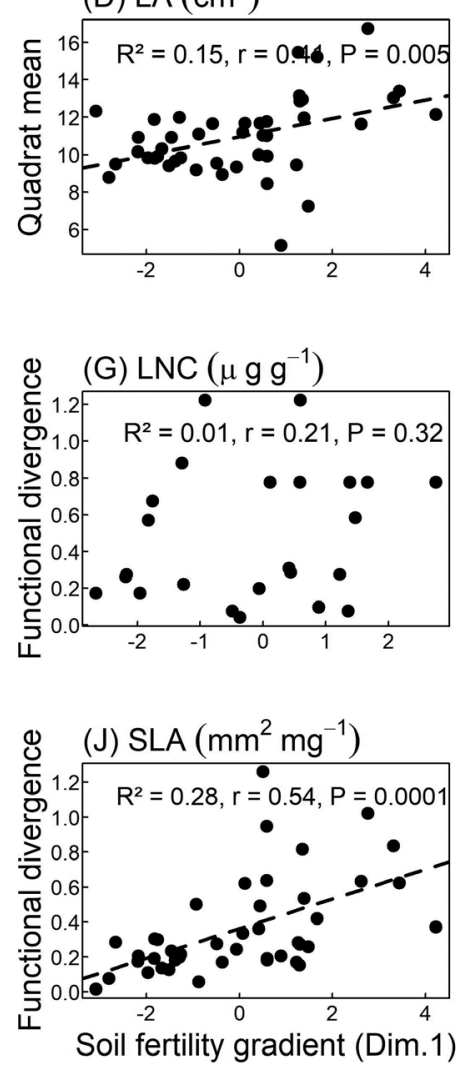

(E) SLA $\left(\mathrm{mm}^{2} \mathrm{mg}^{-1}\right)$
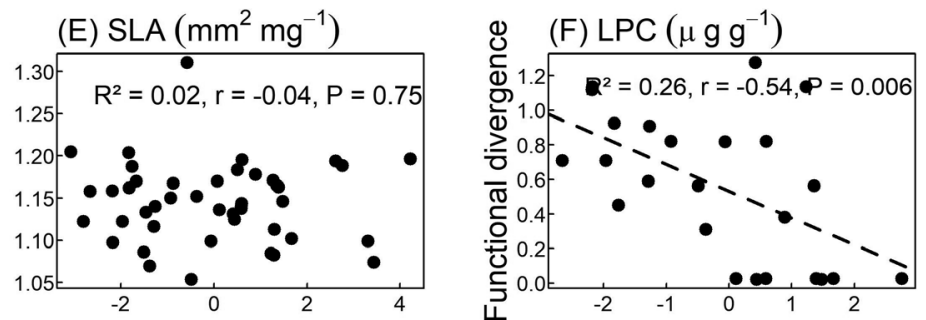

(H) N:P ratio

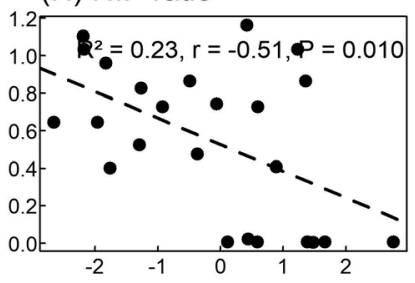

Soil fertility gradient (Dim.1)

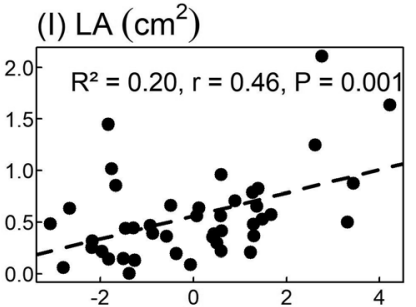

Soil fertility gradient (Dim.1)

Figure 2 - Association of quadrat-level weighted mean (A-E) and functional divergence (F-J) with the soil fertility gradient (Dim.1; first principal component axis) for five traits (LA: leaf area; SLA: specific leaf area; LPC: leaf phosphorus content; LNC: leaf nitrogen content). Dashed lines represent the slope of the linear regression; adjusted coefficient of variation (R2), Pearson correlations (r) and the degree of significance $(\mathrm{P})$ are indicated. SLA and LNC were log transformed while LA, LPC and NP ratio were square root transformed. LNC and N:P ratio were measured on four species while LPC, LA and SLA were measured on all 98 species. 
the same direction or in the opposite directions relative to the quadrat-level mean trait (fig. 4). The slope of intraspecific variation ranged between $-0.19-0.0$ for LPC, $-0.51-0.26$ for LNC, -0.23-0.54 for N:P ratio, -5.12-3.89 for LA and -8.333.94 for SLA. Five species showed significant intraspecific trait variation for SLA and three for LA. No species showed any significant intraspecific trait variation among the four species on which LPC, LNC and N:P ratio were analysed (see electronic appendix 4). When the quadrat-level mean trait values were substituted by Dim. 1 (i.e. PCA scores related to quadrats), the results obtained for intraspecific trait variation were similar to the one above (fig. 4).

\section{DISCUSSION}

\section{Community assembly and trait distribution along soil fertility gradient}

Trait-gradient relationships are widely used to study assembly processes operating along an abiotic gradient (Weiher \& Keddy 1995, Schwilk \& Ackerly 2005). These associations have increasingly been recognized as being important to gain insights on species and community strategies (Thuiller et al. 2004, Wright et al. 2005, Spasojevic \& Suding 2012, Jager et al. 2015). It could be expected that leaf traits that are influenced by environmental stress (e.g. decrease in soil fertility)
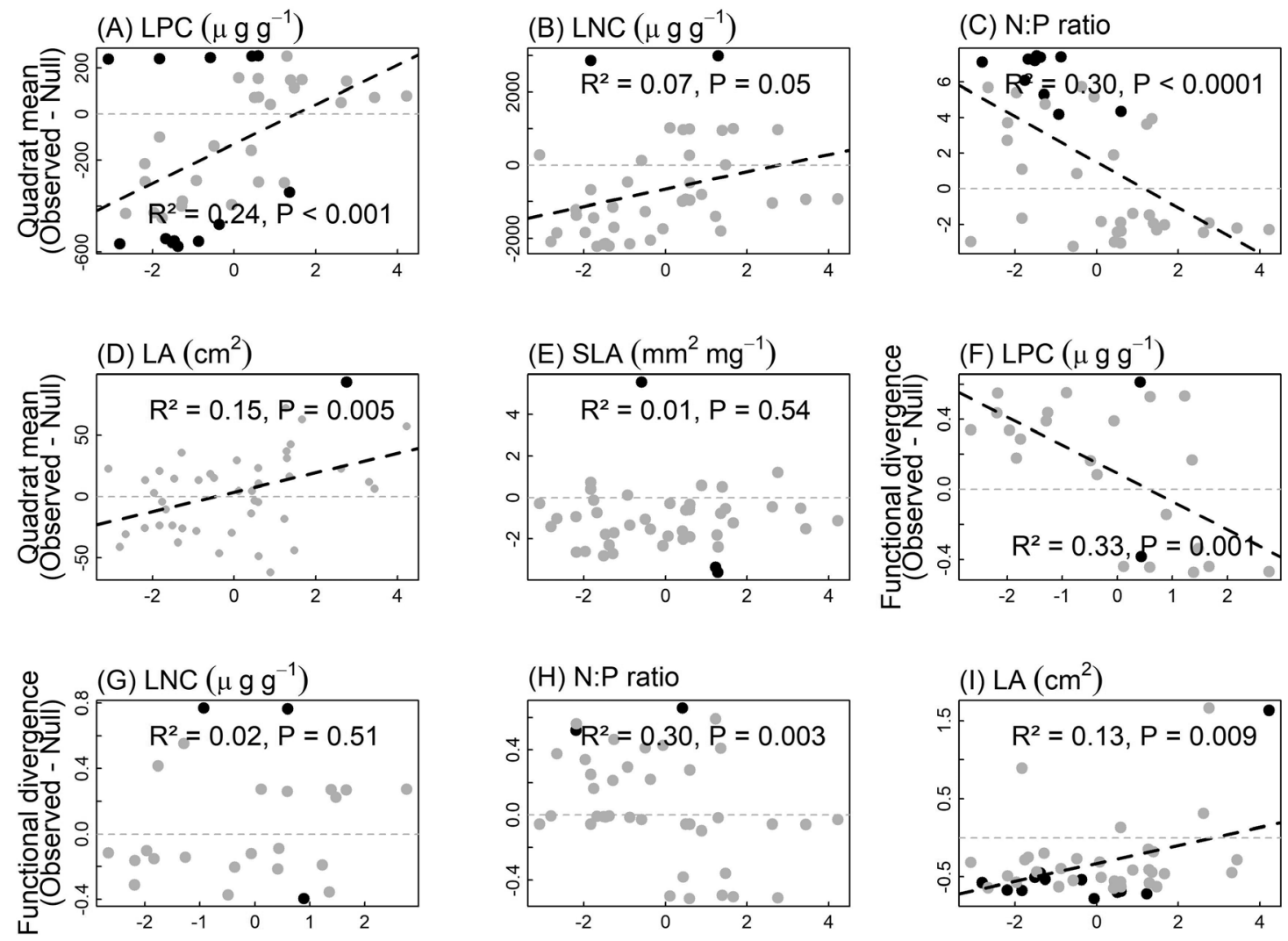

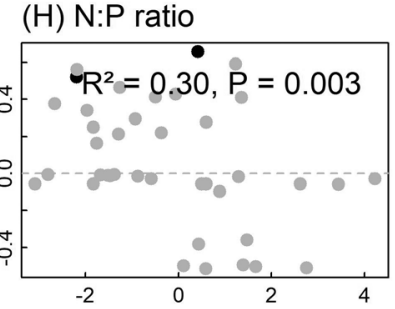

Soil fertility gradient (Dim.1)

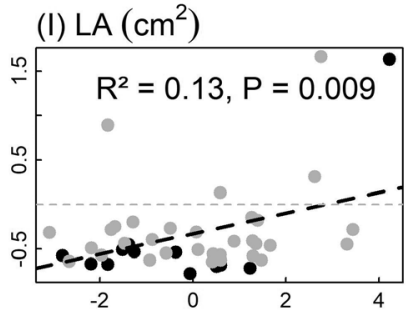

Soil fertility gradient (Dim.1)

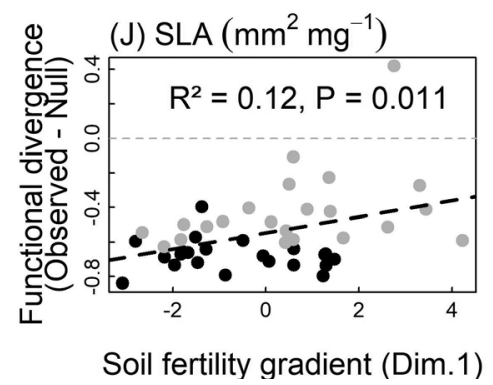

Figure 3 - Departures from non-random trait distribution determined by quadrat-level weighted mean (A-E) and functional divergence (F-J) for individual traits along soil fertility gradient (Dim. 1; first principal component axis). Bold face dots indicate quadrats in which traits were significantly different (positive or negative); grey dots indicate quadrat in which traits were not significantly different from the null assumption of random assembly. Grey (horizontal) dashed lines represent null assumption of random assembly; black dashed lines indicate regression lines of the difference in trait values between observed and null communities versus soil fertility gradient. R2 = adjusted R-squared and $\mathrm{P}=\mathrm{P}$-value $<0.05$. Specific leaf area (SLA) and leaf nitrogen concentration (LNC) were log transformed while Leaf area (LA), leaf phosphorus concentration (LPC) and N:P ratio were square root transformed. LNC and N:P ratio were measured on four species while LPC, LA and SLA were measured on all 98 species. 
would change as the stress in the environment become more present. We found evidence to support this expectation for three of the five traits examined. Quadrat-level mean trait for LPC, LNC and LA significantly decreased for quadrats on less fertile soils and increased correspondingly for quadrats on more fertile soils. This result is consistent with the notion of abiotic filtering for the considered traits (Diaz et al. 1998). The non-significant association of quadrat-level mean trait for SLA to the soil fertility gradient and other soil-related variable (e.g. Topographic Wetness Index: Dilts 2015) was surprising, given that LA (which showed significant association with the gradient) has been reported to be inversely correlated to SLA (Reich et al. 1991). However, LA and SLA were not correlated in our dataset $(r=-0.18)$. An initial analysis where the drainage effect was measured as Topographic Wetness Index, failed to explain the variation of SLA even though a gradient of annual drainage of the 50-ha KFDP is observed (the fertile upper edge of the plot is drier compared to the temporarily wet lower edge; M.B. Libalah, pers. obs.).
This result could mean that SLA did not capture the dispensable filtering of soil fertility and drainage perhaps captured the blurring influence of light intensity although leaves where not sampled from canopy trees because of accessibility constraints. Light penetration through forest strata has been reported to influence the vertical variation of SLA at the upper and lower canopies (Spasojevic et al. 2014, Petter et al. 2016). Given the vertical stratification of tropical forests canopy, it can be speculated that SLA for quadrats with taller trees could have lower SLA values, as an expression of competition for light, compared to SLA for quadrats with shorter trees. High values of LA (low SLA) have also been reported to be correlated to high investment in structural properties such as laminar thickness, high tissue density within the leaf (Reich et al. 1999, Wilson et al. 1999), characteristics that tend to relate to productive local environments.

Functional divergence of LA and SLA increased with the soil fertility gradient, implying the dominance of species with contrasting values for these traits in quadrats with
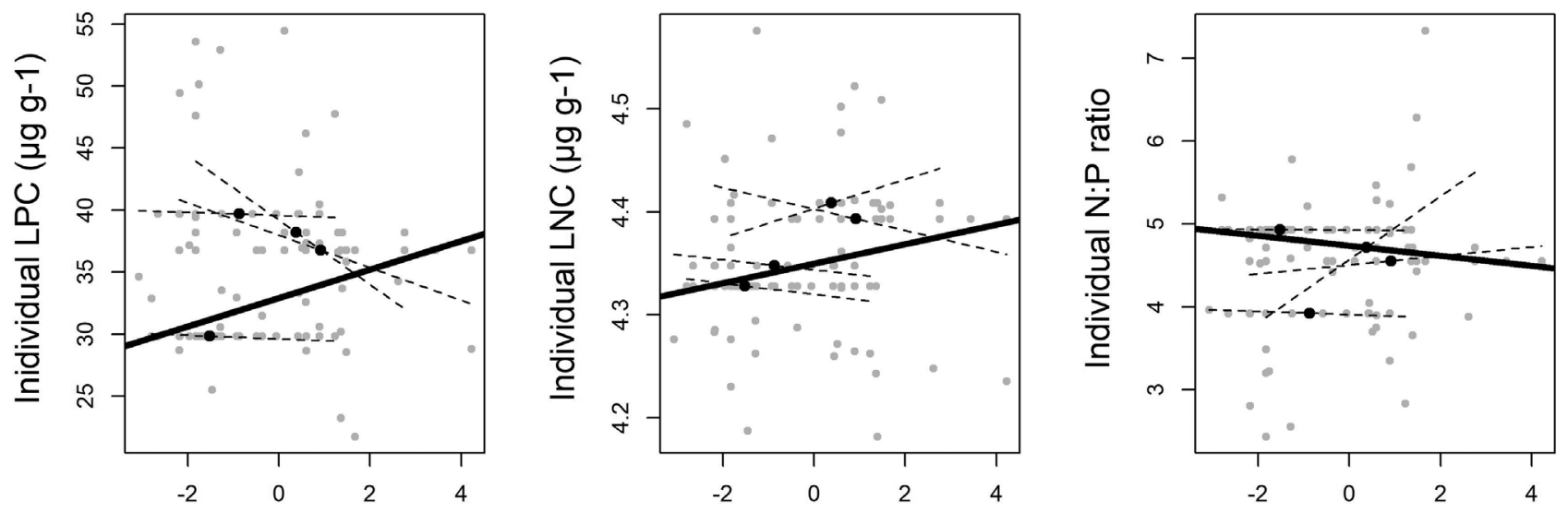

Soil fertility gradient (Dim.1)

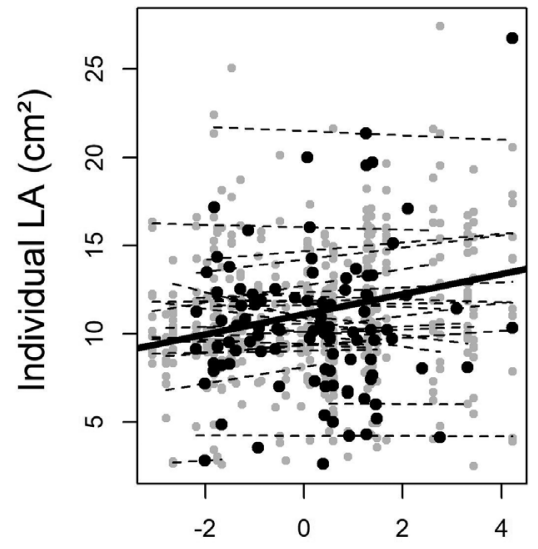

Soil fertility gradient (Dim.1)

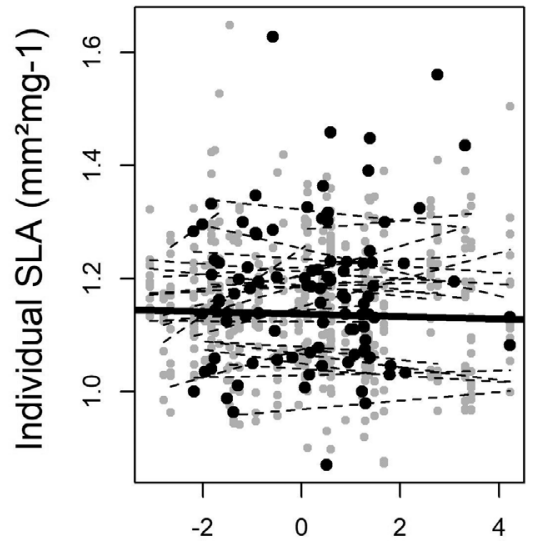

Soil fertility gradient (Dim.1)

Figure 4 - Trends and directions of intraspecific trait variation relative to quadrat-level mean traits along soil fertility gradient. Grey dots and grey dashed lines are species' individual trait values and regression lines for intraspecific trait variation and black dots and black lines are quadrat-level means and regression lines, respectively. Specific leaf area (SLA) and leaf nitrogen concentration (LNC) were log transformed while Leaf area (LA), leaf phosphorus concentration (LPC) and N:P ratio were square root transformed. LNC and N:P ratio were measured on four species while LPC, LA and SLA were measured on all 98 species. 
higher fertility, for which less competition for soil nutrients can be assumed. Congruent with this interpretation is the fact that an increase in soil fertility among quadrats caused a decrease in functional divergence of LPC, pointing that less trait dissimilarity and possibly less competition occurred between species where the soil was more fertile. Given that the soil fertility gradient was dominated by soil properties other than N and P (e.g. CEC and Clay) and was opposed to NIT, the results with LPC cannot be directly linked to P availability in the soil. Therefore the response of LPC could also mean that the advantage for some species having ectomycorrhizal association for $\mathrm{P}$ capture vanishes when $\mathrm{P}$ content increases for the whole community.

Soil fertility is also reported to influence leaf life span, as species on more fertile soils have short-lived leaves because of fast turnover in leaf tissues (Reich et al. 1999). Consistent with previous studies, LPC displayed positive association with increase in soil fertility gradient (Webb et al. 2000, Wright et al. 2001, Ordoñez et al. 2009). We presumed that increase in soil fertility might have increased leaf photosynthetic capacity and biomass allocation to the leaves. In an earlier study, Atwell et al. (1999) noted that phosphorus and nitrogen in leaves are the main source of energy (ATP and NADPH) during metabolic processes and therefore can be related to photosynthetic capacity. Hence the average photosynthetic capacity for tree communities in most of the 50-ha KFDP may be lower relatively to communities towards the upper end of soil fertility gradient.

\section{Non-random community trait distribution along soil fertility gradient}

A shift in community functional traits along an environmental gradient may represent either non-random (deterministic) and random (stochastic) processes that are usually and simultaneously operating among communities (Weiher \& Keddy 1995, Schwilk \& Ackerly 2005). We found evidence for a shift in quadrat-level trait values along soil fertility gradient that partly supported our interpretations for random and non-random processes. Relative to the null expectation (traits are randomly distributed among communities); we noticed that up to $33 \%$ of the variance of among-quadrat traits along the soil fertility gradient was non-randomly distributed. Our results also showed that the partial non-random shift in quadrat-level mean trait and functional divergence, at least for some quadrats (i.e. between 1 and 22 quadrats), departed from the null expectation in both positive and negative directions. The above results suggest that in addition to non-random trait distribution, there was trait convergence (positive deviation) and trait divergence (negative deviation) as the gradient in soil fertility changes. However, considering only abiotic filtering and competitive interaction to infer non-random assembly, may be far from perfect. Integrating assumptions about multiple assembly processes such as facilitation and equalizing fitness processes may improve the performance of testing non-random assembly (Spasojevic \& Suding 2012). Moreover, the set of traits we used is limited to leaf traits and extending the present analysis to wood and whole plant traits could provide more visibility in trait response to soil fertility and community assembly (Jager et al.
2015). Interpretation of assembly processes should be cautious as cancelling out or counteracting assembly rules may be misinterpreted for random assembly.

\section{Trends of intraspecific trait variation}

Earlier studies on functional traits mostly used species mean trait values which largely ignore intraspecific variation. To account for total trait variation, recent studies have begun to include intraspecific trait variation, but have focused largely on the relative contribution vis-à-vis interspecific trait variation (de Bello et al. 2011, Lepš et al. 2011) and sometimes on the influence of intraspecific trait variation on community assembly (Jung et al. 2010, 2014, Siefert 2012). It could also be of importance to study the within species trends relative to mean trait along a gradient (but see Jiang \& Ma 2015, Pescador et al. 2015). Considering that intraspecific trait variation could shift in the same direction as the species mean trait, the trends of intraspecific trait variation may be equal, lower or may show no trends with the gradient (Cornwell \& Ackerly 2009). In relation to these considerations, we recorded 43 species present in three or more quadrats in the 50-ha KFDP and noticed that intraspecific trait variation were always smaller relative to variation in the quadrat-level trait variation. These trends supported that traits vary less within species than between species and intraspecific variation mirrored the quadrat-level trends. These results also suggest that mean trait values and intraspecific variation may both represent the response of genotype in an environment (Ackerly 2003).

\section{CONCLUSION}

We identified soil fertility (in the sense of CEC and Clay content and to a lesser extent of NIT) as the main gradient of soil fertility that determined a shift in functional traits for tree communities in the 50-ha KFDP. The variations of quadrat-level mean traits (i.e. a measure of inter-quadrat trait variation based on species' mean trait value) for LPC, LNC and LA was positively related to an increase in soil fertility. Also, functional divergence (i.e. a measure of trait dissimilarities between co-occurring species) of LA and SLA increased and decreased for LPC and N:P ratio, as the gradient in soil fertility increased. These results suggest that LPC, LNC and LA are shaped by abiotic filtering due to soil fertility and that LPC, N:P ratio, LA and SLA are important in the interspecific competitive interaction process. In addition, the distribution of these traits along the soil fertility gradient was partly accounted for by non-random patterns. Trends in intraspecific trait variation along the soil fertility gradient were consistently shallow relative to the quadrat-level mean traits, suggesting that intraspecific trait variation just reinforced the dominant, overall inter-species variation. Our study on nonrandom trait distribution was limited to two assembly processes: abiotic filtering and competitive interaction whereas other processes such as facilitation and equalizing fitness are also important in the non-random assembly of communities. Also, our study involved only leaf traits whereas abiotic filtering and competitive interaction can also act on belowground traits (e.g. rooting depth, development and type of 
mycorrhizal formation) and eventually influence the distribution of functional traits along the soil fertility gradient.

\section{SUPPLEMENTARY DATA}

Supplementary data are available at Plant Ecology and Evolution, Supplementary Data site (http://www.ingentaconnect. com/content/botbel/plecevo/supp-data) and consists of: (1) list of studied species having a dbh greater than or equal to $10 \mathrm{~cm}$ in the 50-ha Korup Forest Dynamics Plot; (2) spatial distribution of 11 topography and soil-related variables; (3) linear regression between the second (Dim. 2) and third (Dim. 3) principal component axes and quadrat-level weighted mean and functional divergence for four traits; and (4) intraspecific trait slope trends from Jackknife analysis where each species was removed from the calculation of quadratlevel mean trait.

\section{ACKNOWLEDGEMENTS}

This publication was made possible with support from IRDDPF to MBL as a doctoral grant under the programmes "Allocations de recherche pour une thèse au Sud" (ARTS) and "Service de Coopération et d'Action Culturelle" (SCAC) 2014-2017. Field work was financially supported by IFS grant number $\mathrm{D} / 5621-1$. IDEA WILD donated materials for field work. We are thankful to Maxime Réjou-Méchain, Claire Fortunel, Guillaume Delhaye, Pierre Ploton and Nicolas Barbier for initial discussion prior to the development of this paper, to Marko Spasojevic for helping with R codes on null model analysis, to the Plant Systematic and Ecology Laboratory team in Yaoundé for assisting in all field missions and to the authorities of the Korup National park for permission to enter the park. KFDP is financially supported by the Center for Tropical Forest Science - Forest Global Earth Observatory of the Smithsonian Tropical Reseach Institute.

\section{REFERENCES}

Ackerly D.D. (2003) Community assembly, niche conservatism, and adaptive evolution in changing environments. International Journal of Plant Sciences 164: S165-S184. https://doi. org/10.1086/368401

Ackerly D.D., Cornwell W.K. (2007) A trait-based approach to community assembly: partitioning of species trait values into within- and among-community components. Ecology Letters 10: 135-145. https://doi.org/10.1111/j.1461-0248.2006.01006.x

Albert C.H., Thuiller W., Yoccoz N.G., Soudant A., Boucher F., Saccone P., Lavorel S. (2010) Intraspecific functional variability: extent, structure and sources of variation. Journal of Ecology 98: 604-613. https://doi.org/10.1111/j.1365-2745.2010.01651.x

Albert C.H., Grassein F., Schurr F.M., Vieilledent G., Violle C. (2011) When and how should intraspecific variability be considered in trait-based plant ecology? Perspectives in Plant Ecology, Evolution and Systematics 13: 217-225. https://doi. org/10.1016/j.ppees.2011.04.003

Anderson J., Ingram J. (1993) Tropical soil biology and fertility. A handbook of methods. Aberstwyth, CAB International.

Atwell B.J., Kriedemann P.E., Turnbull C.G.N. (1999) Plants in action: adaptation in nature, performance in cultivation. Melbourne, MacMillan Education Australia.
Auger S., Shipley B. (2013) Inter-specific and intra-specific trait variation along short environmental gradients in an old-growth temperate forest. Journal of Vegetation Science 24: 419-428. https://doi.org/10.1111/j.1654-1103.2012.01473.x

Baldeck C.A., Harms K.E., Yavitt J.B., John R., Turner B.L., Valencia R., Navarrete H., Davies S.J., Chuyong G.B., Kenfack D., Thomas D.W., Madawala S., Gunatilleke N., Gunatilleke S., Bunyavejchewin S., Kiratiprayoon S., Yaacob A., Supardi M.N.N., Dalling J.W. (2013) Soil resources and topography shape local tree community structure in tropical forests. Proceedings of the Royal Society B: Biological Sciences 280: 20122532. https://doi.org/10.1098/rspb.2012.2532

Bechem E.E.T., Chuyong G.B., Fon B.T. (2014) A survey of mycorrhizal colonization in the 50-ha Korup Forest Dynamic Plot in Cameroon. American Journal of Plant Sciences 5: 1403-1415. https://doi.org/10.4236/ajps.2014.510155

Bolnick D.I., Amarasekare P., Araújo M.S., Bürger R., Levine J.M., Novak M., Rudolf V.H.W., Schreiber S.J., Urban M.C., Vasseur D.A. (2011) Why intraspecific trait variation matters in community ecology. Trends in Ecology \& Evolution 26: 183-192. https://doi.org/10.1016/j.tree.2011.01.009

Borcard D., Gillet F., Legendre P. (2011) Numerical ecology with R. New York, Springer. https://doi.org/10.1007/978-1-44197976-6

Borianne P., Brunel G. (2012) Automated valuation of leaves area for large-scale analysis needing data coupling or petioles deletion. In: Proceedings -2012 IEEE $4^{\text {th }}$ International Symposium on plant growth modeling, simulation, visualization and applications, PMA 2012: 50-57. https://doi.org/10.1109/ PMA.2012.6524812

Botta-Dukát Z. (2005) Rao's quadratic entropy as a measure of functional diversity based on multiple traits. Journal of Vegetation Science 16: 533-540. https://doi.org/10.1658/11009233(2005)16[533:RQEAAM]2.0.CO;2

Bouyoucos G.J. (1951) A recalibration of the hydrometer method for making mechanical analysis of soils. Agronomy Journal 43: 434-438. https://doi.org/10.2134/agronj1951.00021962004300 090005x

Buondonno A., Rashad A.A., Coppola E. (1995) Comparing tests for soil fertility. II. The hydrogen peroxide/sulfuric acid treatment as an alternative to the copper/selenium catalyzed digestion process for routine determination of soil nitrogen-kjeldahl. Communications in Soil Science and Plant Analysis 26: 1607 1619. https://doi.org/10.1080/00103629509369394

Chave J., Coomes D., Jansen S., Lewis S.L., Swenson N.G., Zanne A.E. (2009) Towards a worldwide wood economics spectrum. Ecology letters 12: 351-366. https://doi.org/10.1111/j.14610248.2009.01285.x

Chesson P. (2000) Mechanisms of maintenance of species diversity. Annual Review of Ecology and Systematics 31: 343-366. https://doi.org/10.1146/annurev.ecolsys.31.1.343

Chuyong G.B., Condit R., Kenfack D., Losos E.C., Moses S.N., Songwe N.C., Thomas D.W. (2004) Korup Forest Dynamics Plot, Cameroon. In: Losos E.C., Leigh Jr. E.G. (eds) Tropical forest diversity and dynamism: findings from a large-scale plot network: 505-516. Chicago, Chicago University Press.

Chuyong G.B., Kenfack D., Harms K.E., Thomas D.W., Condit R., Comita L.S. (2011) Habitat specificity and diversity of tree species in an African wet tropical forest. Plant Ecology 212: 1363 1374. https://doi.org/10.1007/s11258-011-9912-4

Cornelissen J., Lavorel S., Garnier E., Díaz S., Buchmann N.D., Gurvich D.E., Reich P.B., ter Steege H., Morgan H.D.G., van der Heijden M.G.A., Pausas J.G., Poorter H. (2003) A hand- 
book of protocols for standardised and easy measurement of plant functional traits worldwide. Australian Journal of Botany 51: 335-380. https://doi.org/10.1071/BT02124

Cornwell W.K., Ackerly D.D. (2009) Community assembly and shifts in plant trait distributions across an environmental gradient in coastal California. Ecological Monographs 79: 109-126. https://doi.org/10.1890/07-1134.1

Day P.R. (1953) Experimental confirmation of hydrometer theory. Soil Science 75: 181-186.

de Bello F., Lavorel S., Albert C.H., Thuiller W., Grigulis K., Dolezal J., Janeček Š., Lepš J. (2011) Quantifying the relevance of intraspecific trait variability for functional diversity. Methods in Ecology and Evolution 2: 163-174. https://doi.org/10.1111/ j.2041-210X.2010.00071.x

de Bello F., Lavorel S., Lavergne S., Albert C.H., Boulangeat I., Mazel F., Thuiller W. (2013) Hierarchical effects of environmental filters on the functional structure of plant communities: a case study in the French Alps. Ecography 36: 393-402. https://doi.org/10.1111/j.1600-0587.2012.07438.x

Díaz S., Cabido M. (1997) Plant functional types and ecosystem function in relation to global change. Journal of vegetation science 8: 463-474. https://doi.org/10.2307/3237198

Diaz S., Cabido M., Casanoves F. (1998) Plant functional traits and environmental filters at a regional scale. Journal of Vegetation Science 9: 113-122. https://doi.org/10.2307/3237229

Díaz S., Kattge J., Cornelissen J.H.C., Wright I.J., Lavorel S., Dray S., Reu B., Kleyer M., Wirth C., Prentice I.C., Garnier E., Bönisch G., Westoby M., Poorter H., Reich P.B., Moles A.T., Dickie J., Gillison A.N., Zanne A.E., Chave J., Wright S.J., Sheremet'ev S.N., Jactel H., Christopher B., Cerabolini B., Pierce S., Shipley B., Kirkup D., Casanoves F., Joswig J.S., Günther A., Falczuk V., Rüger N., Mahecha M.D., Gorné L.D. (2015) The global spectrum of plant form and function. Nature 529: 167-171. https://doi.org/10.1038/nature16489

Dilts T.E. (2015) Topography Tools for ArcGIS 10.1. University of Nevada Reno. Available at http://www.arcgis.com/home/item. html?id=b13b3b40fa3c43d4a23a1a09c5fe96b9 [accessed 20 Nov. 2015].

Engelbrecht B.M.J., Kursar T.A. (2003) Comparative droughtresistance of seedlings of 28 species of co-occurring tropical woody plants. Oecologia 136: 383-393. https://doi.org/10.1007/ s00442-003-1290-8

ESRI (2016) ArcGIS ver. 10.4.1 for desktop. Redlands, CA.

Ewango C.E.N., Kenfack D., Sainge M.N., Thomas D.W., van der Burgt X.M. (2016) Gambeya korupensis (Sapotaceae: Chrysophylloideae), a new rain forest tree species from the Southwest Region in Cameroon. Kew Bulletin 71: 28. https://doi. org/10.1007/s12225-016-9633-x

Gartlan J.S., Newbery D.M., Thomas D.W., Waterman P.G. (1986) The influence of topography and soil phosphorus on the vegetation of Korup Forest Reserve, Cameroun. Vegetatio 65: 131148. https://doi.org/10.1007/BF00044814

Heanes D.L. (1984) Determination of total organic-C in soils by an improved chromic acid digestion and spectrophotometric procedure. Communications in Soil Science and Plant Analysis 15: 1191-1213. https://doi.org/10.1080/00103628409367551

HilleRisLambers J., Adler P.B., Harpole W.S., Levine J.M., Mayfield M.M. (2012) Rethinking community assembly through the lens of coexistence theory. Annual Review of Ecology, Evolution, and Systematics 43: 227-248. https://doi.org/10.1146/ annurev-ecolsys-110411-160411

Hulshof C.M., Swenson N.G. (2010) Variation in leaf functional trait values within and across individuals and species: an ex- ample from a Costa Rican dry forest. Functional Ecology 24: 217-223. https://doi.org/10.1111/j.1365-2435.2009.01614.x

Jager M.M., Richardson S.J., Bellingham P.J., Clearwater M.J., Laughlin D.C. (2015) Soil fertility induces coordinated responses of multiple independent functional traits. Journal of Ecology 103: 374-385. https://doi.org/10.1111/1365-2745.12366

Jiang Z., Ma K. (2015) Environmental filtering drives herb community composition and functional trait changes across an elevational gradient. Plant Ecology and Evolution 148: 301-310. https://doi.org/10.5091/plecevo.2015.1124

John M.K. (1970) Colorimetric determination of phosphorus in soil and plant materials with ascorbic acid. Soil Science 109: 214-220.

Jung V., Violle C., Mondy C., Hoffmann L., Muller S. (2010) Intraspecific variability and trait-based community assembly. Journal of Ecology 98: 1134-1140. https://doi.org/10.1111/ j.1365-2745.2010.01687.x

Jung V., Albert C.H., Violle C., Kunstler G., Loucougaray G., Spiegelberger T. (2014) Intraspecific trait variability mediates the response of subalpine grassland communities to extreme drought events. Journal of Ecology 102: 45-53. https://doi. org/10.1111/1365-2745.12177

Keddy P.A. (1992) Assembly and response rules: two goals for predictive community ecology. Journal of Vegetation Science 3: 157-164. https://doi.org/10.2307/3235676

Kenfack D., Thomas D.W., Chuyong G., Condit R. (2007) Rarity and abundance in a diverse African forest. Biodiversity and Conservation 16: 2045-2074. https://doi.org/10.1007/s10531006-9065-2

Kenfack D., Gereau R.E., Thomas D.W., Sainge M.N. (2015) The tropical African genus Crotonogynopsis (Euphorbiaceae), with two new species. Novon: A Journal for Botanical Nomenclature 24: 246-255. https://doi.org/10.3417/2015005

Kichenin E., Wardle D.A., Peltzer D.A., Morse C.W., Freschet G.T. (2013) Contrasting effects of plant inter- and intraspecific variation on community-level trait measures along an environmental gradient. Functional Ecology 27: 1254-1261. https://doi. org/10.1111/1365-2435.12116

Laliberté A.E., Legendre P., Shipley B. (2014) FD: measuring functional diversity from multiple traits, and other tools for functional ecology. R package: 0-12. Available from http://cran.rproject.org/web/packages/FD/FD.pdf [accessed 25 Aug. 2015].

Lavorel S., Garnier E. (2002) Predicting changes in community composition and ecosystem functioning from plant traits: revisiting the Holy Grail. Functional Ecology 16: 545-556. https:// doi.org/10.1046/j.1365-2435.2002.00664.x

Lavorel S., Grigulis K., McIntyre S., Williams N.S.G., Garden D., Dorrough J., Berman S., Quétier F., Thébault A., Bonis A. (2008) Assessing functional diversity in the field - methodology matters! Functional Ecology 22: 134-147. https://doi. org/10.1111/j.1365-2435.2007.01339.x

Lê S., Josse J., Husson F. (2008) FactoMineR: an R package for multivariate analysis. Journal of Statistical Software 25: 1-18. https://doi.org/10.18637/jss.v025.i01

Lepš J., de Bello F., Šmilauer P., Doležal J. (2011) Community trait response to environment: disentangling species turnover vs intraspecific trait variability effects. Ecography 34: 856-863. https://doi.org/10.1111/j.1600-0587.2010.06904.x

Letouzey R. (1985) Notice de la carte phytogéographique du Cameroun au 1/500 000. Toulouse, Institut de la carte Internationale de la Végétation.

Libalah M.B., Fongod A.G.N., Veranso M.C., Kenfack D. (2014) Field and morphometric studies of Phyllobotryon Müell.Arg. 
(Salicaceae) in the Korup Forest Area of Cameroon. Adansonia 36: 303-313. https://doi.org/10.5252/a2014n2a10

Macarthur R., Levins R. (1967) The limiting similarity, convergence, and divergence of coexisting species. The American Naturalist 101: 377-385. https://doi.org/10.1086/282505

Maley J. (1998) La forêt dense humide Africaine: principales caractéristiques des changements de végétation et de climat du Crétacé supérieur au Quaternaire. In: Watley R., Swaine M.D., Alexander I.J. (eds) West African Forests: studies in the Guineo-Congolian Domain: 1-29. Edinburgh, The Royal Society of Edinburgh.

Mason N.W.H., Mouillot D., Lee W.G., Wilson J.B. (2005) Functional richness, functional evenness and functional divergence: the primary components of functional diversity. Oikos 111: 112-118. https://doi.org/10.1111/j.0030-1299.2005.13886.x

McGill B.J., Enquist B.J., Weiher E., Westoby M. (2006) Rebuilding community ecology from functional traits. Trends in Ecology \& Evolution 21: 178-185. https://doi.org/10.1016/j. tree.2006.02.002

Mouchet M.A., Villéger S., Mason N.W.H., Mouillot D. (2010) Functional diversity measures: an overview of their redundancy and their ability to discriminate community assembly rules. Functional Ecology 24: 867-876. https://doi.org/10.1111/ j.1365-2435.2010.01695.x

Murphy J., Riley J.P. (1962) A modified single solution method for the determination of phosphate in natural waters. Analytica Chimica Acta 27: 31-36. https://doi.org/10.1016/S00032670(00)88444-5

Newbery D.M., Alexander I.J., Thomas D.W., Gartlan J.S. (1988) Ectomycorrhizal rain-forest legumes and soil phosphorus in Korup National Park, Cameroon. New Phytologist 109: 433450. https://doi.org/10.1111/j.1469-8137.1988.tb03719.x

Newbery D.M., Songwe N.C., Chuyong G.B. (1998) Phenology and dynamics of an African rainforest at Korup, Cameroon. In: Newberry D.M., Prins H.H.T., Brown N. (eds) Dynamics of tropical communities. $37^{\text {th }}$ Symposium of the British Ecological Society: 267-308. Oxford, Blackwell Science Ldt.

Oksanen J., Blanchet F.G., Kindt R., Legendre P., O'Hara R.B., Simpson G.L., Solymos P., Stevens M.H.H., Wagner H. (2012) vegan: Community Ecology Package. R package version 2.0.3. Available from https://cran.r-project.org/package=vegan [accessed 27 Jun. 2017].

Ordoñez J.C., van Bodegom P.M., Witte J.-P.M., Wright I.J., Reich P.B., Aerts R. (2009) A global study of relationships between leaf traits, climate and soil measures of nutrient fertility. Global Ecology and Biogeography 18: 137-149. https://doi. org/10.1111/j.1466-8238.2008.00441.x

Paoli G.D. (2006) Divergent leaf traits among congeneric tropical trees with contrasting habitat associations on Borneo. Journal of Tropical Ecology 22: 397-408. https://doi.org/10.1017/ S0266467406003208

Pescador D.S., de Bello F., Valladares F., Escudero A. (2015) Plant trait variation along an altitudinal gradient in Mediterranean high mountain grasslands: controlling the species turnover effect. PloS ONE 10: e0118876. https://doi.org/10.1371/journal. pone. 0118876

Petter G., Wagner K., Wanek W., Sánchez Delgado E.J., Zotz G., Cabral J.S., Kreft H. (2016) Functional leaf traits of vascular epiphytes:vertical trends within the forest, intra- and interspecific trait variability, and taxonomic signals. Functional Ecology 30: 188-198. https://doi.org/10.1111/1365-2435.12490

R Development Core Team (2015) R: a language and environment for statistical computing. Ver. 3.2.2. Vienna, R Foundation for
Statistical Computing. Available from http://www.r-project.org/ [accessed 1 Sep. 2015].

Reich P.B., Uhl C., Walters M.B., Ellsworth D.S. (1991) Leaf lifespan as a determinant of leaf structure and function among 23 amazonian tree species. Oecologia 86: 16-24. https://doi. org/10.1007/BF00317383

Reich P.B., Ellsworth D.S., Walters M.B., Vose J.M., Gresham C., Volin J.C., Bowman W.D. (1999) Generality of leaf trair relationships: a test across six biomes. Ecology 80: 1955-1969. https://doi.org/10.1890/0012-9658(1999)080[1955:GOLTRA]2 .0. $\mathrm{CO} ; 2$

Reich P.B. (2014) The world-wide 'fast-slow' plant economics spectrum: a traits manifesto. Journal of Ecology 102: 275-301. https://doi.org/10.1111/1365-2745.12211

Schwilk D.W., Ackerly D.D. (2005) Limiting similarity and functional diversity along environmental gradients. Ecology Letters 8: 272-281. https://doi.org/10.1111/j.1461-0248.2004.00720.x

Shipley B., Lechowicz M.J., Wright I., Reich P.B. (2006) Fundamental trade-offs generating the worldwide leaf economics spectrum. Ecology 87: 535-541. https://doi.org/10.1890/051051

Siefert A. (2012) Incorporating intraspecific variation in tests of trait-based community assembly. Oecologia 170: 767-775. https://doi.org/10.1007/s00442-012-2351-7

Siefert A., Fridley J.D., Ritchie M.E. (2014) Community functional responses to soil and climate at multiple spatial scales: when does intraspecific variation matter? PLoS ONE 9: e111189. https://doi.org/10.1371/journal.pone.0111189

Spasojevic M.J., Suding K.N. (2012) Inferring community assembly mechanisms from functional diversity patterns: the importance of multiple assembly processes. Journal of Ecology 100: 652-661. https://doi.org/10.1111/j.1365-2745.2011.01945.x

Spasojevic M.J., Yablon E.A., Oberle B., Myers J.A. (2014) Ontogenetic trait variation influences tree community assembly across environmental gradients. Ecosphere 5: 1-20. https://doi. org/10.1890/ES14-000159.1

Thomas D.W., Kenfack D., Chuyong G.B., Moses S.N., Losos E.C., Condit R.S., Songwe N.C. (2003) Tree species of Southwestern Cameroon: tree distribution maps, diameter tables, and species documentation of the 50-hectare Korup Forest Dynamics Plot. Washington, D.C., Center for Tropical Forest Science of the Smithsonian Tropical Research Institute and Bioresources Development and Conservation Programme - Cameroon.

Thuiller W., Lavorel S., Midgley G., Lavergne S., Rebelo T. (2004) Relating plant traits and species distributions along bioclimatic gradients for 88 Leucadendron taxa. Ecology 85: 1688-1699. https://doi.org/10.1890/03-0148

Villéger S., Mason N.W.H., Mouillot D. (2008) New multidimensional functional diversity indices for a multifaceted framwork in functional ecology. Ecology 89: 2290-2301. https://doi. org/10.1890/07-1206.1

Violle C., Enquist B.J., McGill B.J., Jiang L., Albert C.H., Hulshof C., Jung V., Messier J. (2012) The return of the variance: intraspecific variability in community ecology. Trends in Ecology \& Evolution 27: 244-252. https://doi.org/10.1016/j. tree.2011.11.014

Webb M.J., Reddell P., Hambleton A., Robson K. (2000) Growth response of four tropical plantation timber species to increasing phosphorus supply and assessment of phosphorus requirements using foliar analysis. New Forests 20: 193-211. https:// doi.org/10.1023/A:1006756105284 
Weiher E., Keddy P.A. (1995) The assembly of experimental wetland plant communities. Oikos 73: 323-335. https://doi. org/10.2307/3545956

Weiher E., Clarke G.D.P., Keddy P.A. (1998) Community assembly rules, morphological dispersion, and the coexistence of plant species. Oikos 81: 309-322. https://doi.org/10.2307/3547051

Westoby M., Falster D.S., Moles A.T., Vesk P.A., Wright I.J. (2002) Plant ecological strategies: some leading dimensions of variation between species. Annual Review of Ecology and Systematics 33: 125-159. https://doi.org/10.1146/annurev.ecolsys.33.010802.150452

Wilson P.J., Thompson K., Hodgson J.G. (1999) Specific leaf area and dry leaf matter content as alternative predictors of plant strategies. New Phytologist 143: 155-162. https://doi. org/10.1046/j.1469-8137.1999.00427.x

Wright I.J., Reich P.B., Westoby M. (2001) Strategy shifts in leaf physiology, structure and nutrient content between species of high- and low-rainfall and high- and low-nutrient habitats. Functional Ecology 15: 423-434. https://doi.org/10.1046/ j.0269-8463.2001.00542.x

Wright I.J., Reich P.B., Westoby M., Ackerly D.D., Baruch Z., Bongers F., Cavender-Bares J., Chapin T., Cornelissen J.H.C.,
Diemer M., Flexas J., Garnier E., Groom P.K., Gulias J., Hikosaka K., Lamont B.B., Lee T., Lee W., Lusk C., Midgley J.J., Navas M.-L., Niinemets Ü., Oleksyn J., Osada N., Poorter H., Poot P., Prior L., Pyankov V.I., Roumet C., Thomas S.C., Tjoelker M.G., Veneklaas E.J., Villar R. (2004) The worldwide leaf economics spectrum. Nature 428: 821-827. https://doi. org/10.1038/nature02403

Wright I.J., Reich P.B., Cornelissen J.H.C., Falster D.S., Groom P.K., Hikosaka K., Lee W., Lusk C.H., Niinemets Ü., Oleksyn J., Osada N., Poorter H., Warton D.I., Westoby M. (2005) Modulation of leaf economic traits and trait relationships by climate. Global Ecology and Biogeography 14: 411-421. https://doi. org/10.1111/j.1466-822x.2005.00172.x

Xia S.-W., Chen J., Schaefer D., Detto M. (2015) Scale-dependent soil macronutrient heterogeneity reveals effects of litterfall in a tropical rainforest. Plant and Soil 391: 51-61. https://doi. org/10.1007/s11104-015-2402-Z

Manuscript received 23 Dec. 2016; accepted in revised version 27 Jun. 2017.

Communicating Editor: Hans ter Steege. 